Compared to last year, the demand for the specialty «Public Administration» increased in the TOP-10.

Thus, there is a steady demand for economic specialties in the market of educational services of Ukraine, especially high demand is observed for the specialty «International Economic Relations».

\title{
References:
}

1. Zakonodavstvo Ukrajiny (2019). Pro zatverdzhennja pereliku ghaluzej znanj $i$ specialjnostej, za jakymy zdijsnjujetjsja pidghotovka zdobuvachiv vyshhoji osvity: Postanova Kabinetu Ministriv Ukrajiny vid 29 kvitnja 2015 roku \# 266 [On approval of the list of branches of knowledge and specialties for which higher education applicants are trained: Resolution of the Cabinet of Ministers of Ukraine of April 29, 2015 No. 266]. Retrieved from: https://zakon.rada.gov.ua/laws/show/266-2015\%D0\%BF (accessed 10 February 2020).

2. Zakonodavstvo Ukrajiny (2019). Pro vyshhu osvitu: Zakon Ukrajiny vid 01.07.2014 \# 1556-VII (redakcija vid 09.08.2019) [On Higher Education: Law of Ukraine dated 01.07.2014 № 1556-VII (edition of 09.08.2019)]. Retrieved from: https://zakon.rada.gov.ua/laws/show/1556-18 (accessed 10 February 2020).

3. Map of first higher education degrees of European country leaders. Retrieved from: https://www.reddit.com/r/europe/comments/7exmd4/map_of_first_higher_ education_degrees_of_european/ (accessed 10 February 2020).

4. Ministerstvo osvity i nauky Ukrajiny (2019). TOP-10 specialjnostej $z$ najvyshhymy prokhidnymy balamy u 2019 roci [Top 10 specialties with highest passing points in 2019]. Retrieved from: https://mon.gov.ua/ua/news/top-10-specialnostej-znajbilshimi-prohidnimi-balami-2019-roku (accessed 10 February 2020).

\section{PROTEIN CONSUMPTION LIKE A FOOD SECURITY INDEX OF THE COUNTRY}

\section{Natela Kordzaia ${ }^{1}$ \\ Bogdan Iegorov ${ }^{2}$}

DOI: https://doi.org/10.30525/978-9934-588-39-6-49

A global food security problem today is more than ever.

There is no country in the world that is concerned with food security. This includes food products production, their distribution, domestic consumption, imports and exports, etc. However, each country has its own features of

\footnotetext{
${ }^{1}$ Odessa National Academy of Food Technologies, Ukraine

${ }^{2}$ Odessa National Academy of Food Technologies, Ukraine
} 
improving the food supply of its population, depending on the level achieved in solving this problem and the impact of various factors [1].

According to the Food and Agriculture Organization of the United Nations (FAO) experts «Food security exists when all people, at all times, have physical and economic access to sufficient, safe and nutritious food that meets their dietary needs and food preferences for an active and healthy life» [1-3].

The term «food security» includes quite a few major elements of which recognized the quality of foods that people consume [1]. And the basic food products quality are its physicochemical properties, namely the chemical composition, that is the content and ratio of the main nutrients - proteins, fats, carbohydrates, micro and macronutrients, vitamins and others.

The greatest attention is always paid, primarily protein compounds (proteins), because they are the basis of all the cells of living beings.

The problem of protein nutrition in the modern world is quite important, but unfortunately, this problem is not given proper attention in the territory of our country and its neighboring countries.

Among the most famous scientists who deal with the regulation of the consumption of the necessary substances of the human body substances can be distinguished Ukrainian Professor Smolyar V. [4], American scientists Guoyao Wu [5], Millward, D.J. [6], Rand W. [7]; Australian scientist Nowson C. [8]; researchers from the UK Lonnie M. [9]; the Swedish scientist Hörnell A. [10] and others.

Today, there are many recommendations from the world organizations and well-known scientists on the correct protein nutrition, which can ensure the proper functioning of the human body. At the same time, there are almost no common guidelines for protein intake for the different age groups.

According to the collaborative work of a team of scientists such as $\mathrm{J}$. Amaya-Farfán, B. Beaufrère, N. Butte et al., as well as by scientists and specialists from WHO, FAO and the UN, the optimal level of protein consumption by children from birth to 4 months should be from $1.77 \mathrm{~g} / \mathrm{kg}$ body weight per day at the age of 1 month to $1.24 \mathrm{~g} / \mathrm{kg}$ body weight per day at the age of 4 months [11]. For children age of 1, 5 and 10 years, protein intake recommendations are $1.31 ; 0.85$ and $0.91 \mathrm{~g} / \mathrm{kg}$ body weight per day, respectively [11].

As for the features of protein nutrition in adolescence, it can be said that the existing recommendations in the world today are quite different.

Thus, according to research by scientists of the Institute of Medicine of the National Academy of Sciences of the USA, the need for protein for young people aged 18 years is on average $0.93 \mathrm{~g} / \mathrm{kg}$ body weight per day [12]. And according to the Ministry of Health of New Zealand, boys aged 15... 18 years 
should consume protein at $0.99 \mathrm{~g} / \mathrm{kg}$ body weight per day, girls of the same age $-0.77 \mathrm{~g} / \mathrm{kg}$ respectively [13].

For adults, according to the recommendations of WHO, FAO and the UN can be considered the minimum level of protein intake on level $0.83 \mathrm{~g} / \mathrm{kg}$ body weight per day [11], although in the studies of American scientists Rand W., Pellett P. and Young V. was found a minimum need for protein consumption by adults at the level of $0.66 \mathrm{~g} / \mathrm{kg}$ body weight per day [7]. These results are consistent with the results of studies by another American at the Institute of Medicine of the US National Academy of Sciences, who also established a protein requirement for adults at $0.66 \mathrm{~g} / \mathrm{kg}$ body weight per day [12].

It should be noted that based on age and gender, the need for not only total protein but also protein of animal origin is changing [10; 14]. Thus, at the beginning of life, the human body, regardless of gender, requires the same amount of animal protein. The proportion of animal protein in the daily requirement, both for boys and girls aged $0-3$ months is $100 \%$. Further, this amount decreases a little and is at the following levels: at the age of 4-6 months $-96 \%$, at the age of $1-3$ years $-79 \%$, at the age of $4-7$ years $70 \%$, at the age of $7-10$ years $-71 \%$. Then, girls' need for protein before reaching the age of 18 does not change and is at $71 \%$, and for boys this need increases to $73-74 \%$ aged of $11-17$. For adults, the proportion of protein of animal origin should be at level of $50 \%$, regardless of age, gender and physical activity $[10 ; 14]$. Although such recommendations are contrary to the results of Guoyao Wu research [5]. Thus, it can be said that the average need for protein of animal origin for children aged one year to 17 years is $71.8 \%$ for boys and $70.8 \%$ for girls, for adults this figure for the entire lifetime is $50 \%[10 ; 14]$. But the results of studies conducted by a team of British scientists, such as Lonnie M., Hooker E., Brunstrom J., Corfe B.M., the actual average daily intake of animal protein adults was $60 \%$ [9].

As a result of a careful analysis of the world-wide recommendations on protein nutrition of the population of the country, and in particular of protein intake, we can speak of the following. As a result of a careful analysis of the world-wide recommendations on protein nutrition of the population of the country, and in particular of protein intake, we can speak of the following. To calculate the needs for high-protein foods to ensure the nutritional status of the Ukrainian population at the physiological needs, the average norms of daily protein intake can be taken at the following levels:

- $1.34 \mathrm{~g} / \mathrm{kg}$ body weight per day for boys and $1.39 \mathrm{~g} / \mathrm{kg}$ body weight per day for girls up to 1 year old inclusive;

- 0,96 ... 1,0 g/kg of body weight per day for children aged 2... 3 years;

$-0.85 \ldots 0.94 \mathrm{~g} / \mathrm{kg}$ body weight per day for children aged $4 . . .6$ years;

$-0.86 \ldots 0.88 \mathrm{~g} / \mathrm{kg}$ body weight per day for children aged $7 \ldots 10$ years; 
- $0.97 \ldots 0.94 \mathrm{~g} / \mathrm{kg}$ body weight per day for children aged $11 \ldots 14$ years;

$-0.92 \ldots 0.87 \mathrm{~g} / \mathrm{kg}$ body weight per day for boys and girls aged $15 \ldots 18$ years;

- $0.78 \mathrm{~g} / \mathrm{kg}$ body weight per day for adults (19... 59 years);

- $1.02 \mathrm{~g} / \mathrm{kg}$ body weight per day for people aged $60 . .664$ years;

- $1.17 \mathrm{~g} / \mathrm{kg}$ body weight per day for body weight for people 75 years and older.

Also it should be taken into account that the need for animal protein (as a percentage of total consumption) will be at the following levels: $79 \%$ for children from birth to 1 year inclusive; $70 \ldots 74 \%$ for children aged 2 ....18 years; $50 \%$ for adults and seniors.

Defined norms of protein nutrition of the population of the country will allow to provide quality and benefit of domestic food products, thereby increasing its competitiveness in comparison with imported counterparts. And the high quality and competitiveness of the country's food is the key to improving its food security.

In the future, the continuation of this study can be a calculation of the average actual population protein consumption in Ukraine and to compare these values with recommended.

\section{References:}

1. Rome Declaration on World Food Security, 13-17.11.1996. URL: http://www.fao.org/docrep/003/w3613e/w3613e00

2. Kordzaya, N.R., \& Egorov, B.V. (2018). Osnovni ponyattya prodovol'choï bezpeki kraïni. Xerson: Oldi-Plyus.

3. Deklaracyja Vsemyrnogho Sammyta po prodovoljstvennoj bezopasno-sty Rym, 16-18 nojabrja 2009 ghoda. URL: ftp://ftp.fao.org/docrep/fao/Meeting/ 018/k6050r.pdf

4. Smoliar, V.I. (2000). Fiziolohiia ta hihiiena kharchuvannia. Kyiv: Zdorov'ia.

5. Guoyao, Wu. (2016). Dietary protein intake and human health // Food Funct. № 7. P. 1251-1265.

6. Millward, D.J., Fereday, A., Gibson, N., \& Pacy, P.J. (1999). Ageing, protein requirements and protein turnover. American Journal of Clinical Nutrition, 66, 774-786.

7. Rand, W.M., Pellett, P.L., \& Young, V.R. (2003). Meta-analysis of nitrogen balance studies for estimating protein requirements in healthy adults. American Journal of Clinical Nutrition, 77, 109-127.

8. Nowson C., O’Connell S. Protein Requirements and Recommendations for Older People: A Review/Nutrients. 2015 Aug; 7(8): 6874-6899.

9. Protein for Life: Review of Optimal Protein Intake, Sustainable Dietary Sources and the Effect on Appetite in Ageing Adults/Lonnie M., Hooker E., Brunstrom J.M., Corfe B.M., Green M.A., Watson A.W., Williams E.A., Stevenson E.J., Penson S., Johnstone A.M. // Nutrients. - 2018. - 10(2): 360. URL: https://www.ncbi.nlm.nih.gov/ pmc/articles/PMC5872778/

10. Hörnell A., Lagström H. Lande B., Inga Thorsdottir I. Protein intake from 0 to 18 years of age and its relation to health: a systematic literature review for the 
5th Nordic Nutrition Recommendations/Food Nutr Res. 2013; 57: 10.3402. URL: https://www.ncbi.nlm.nih.gov/pmc/articles/PMC3664059/

11. Protein and amino acid requirements in human nutrition/ WHO technical report series ; no. 935. Report of a Joint WHO/FAO/UNU Expert Consultation. ISBN 978924120935 9. 2002, Geneva, Switzerland. URL: http://apps.who.int/iris/ bitstream/handle/10665/43411/WHO_TRS_935_eng.pdf?ua=1

12. National Academy of Sciences. The Institute of Medicine. Food and Nutrition Board. Dietary Reference Intakes: Energy, Carbohydrate, Fiber, Fat, Fatty Acids, Cholesterol, Protein and Amino Acids. The National Academy Press; Washington, DC, USA: 2005.

13. Food and Nutrition Guidelines for Healthy Children and Young People (Aged 2-18 years): A background paper/Partial revision February Ministry of Health, New Zealand, 2015. Wellington: Ministry of Health. - 2015. - 236 p. URL: https://www.health.govt.nz/system/files/documents/publications/food-nutritionguidelines-healthy-children-young-people-background-paper-feb15-v2.pdf

14. FAO/WHO/UNU. Protein and amino acid requirements in human nutrition. Joint WHO/FAO/UNU Expert Consultation. World Health Organ Tech Rep Ser. 2007: 1-265. [PubMed].

\section{FORMATION OF THE UNION MARKET OF PRODUCTS OF THE EU: EVOLUTION AND LIBERALIZATION}

\section{Inna Ukhanova ${ }^{1}$}

DOI: https://doi.org/10.30525/978-9934-588-39-6-50

The common market of the countries of Europe was established by the Treaty of Rome, according to which, the opportunities for free trade of goods within the European Community should be formed. Such step has made it possible to create a strong foundation for the formation of a common economy, however, as in any movement towards integration, the formation of a single market of goods was accompanied by certain problems. That is why, although today it is believed that the EU common goods market has already been formed, there remain outstanding issues that require the development of additional regulatory documents and an agreed policy among EU governments.

Initially, the free movement of goods was an element of the customs union, later emphasis was placed on removing all barriers to the freedom of

\footnotetext{
${ }^{1}$ Odessa National Economic University, Ukraine
} 